\title{
Ambient formaldehyde measurements made at a remote marine boundary layer site during the NAMBLEX campaign - a comparison of data from chromatographic and modified Hantzsch techniques
}

\author{
T. J. Still ${ }^{1}$, S. Al-Haider ${ }^{1}$, P. W. Seakins ${ }^{1}$, R. Sommariva ${ }^{1}$, J. C. Stanton ${ }^{1}$, G. Mills ${ }^{2}$, and S. A. Penkett ${ }^{2}$ \\ ${ }^{1}$ School of Chemistry, University of Leeds, Leeds, LS2 9JT, UK \\ ${ }^{2}$ School of Environmental Sciences, University of East Anglia, Norwich, NR4 7TJ, UK
}

Received: 9 August 2005 - Published in Atmos. Chem. Phys. Discuss.: 6 December 2005

Revised: 13 June 2006 - Accepted: 13 June 2006 - Published: 6 July 2006

\begin{abstract}
Ambient formaldehyde concentrations are reported from the North Atlantic Marine Boundary Layer Experiment (NAMBLEX) campaign at Mace Head on the west coast of Eire during August 2002. The results from two techniques, using direct determination via gas chromatography and the Hantzsch technique, show similar trends but a significant off set in concentrations. For westerly air flows characteristic of the marine boundary layer, formaldehyde concentrations from the gas chromatographic and Hantzsch technique ranged from $0.78-1.15 \mathrm{ppb}$ and $0.13-0.43 \mathrm{ppb}$, respectively. Possible reasons for the discrepancy have been investigated and are discussed, however, no satisfactory explanation has yet been found. In a subsequent laboratory intercomparison the two techniques were in good agreement.

The observed concentrations have been compared with previous formaldehyde measurements in the North Atlantic marine boundary layer and with other measurements from the NAMBLEX campaign. The measurements from the Hantzsch technique and the GC results lie at the lower and upper ends respectively of previous measurements. In contrast to some previous measurements, both techniques show distinct diurnal profiles with day maxima and with an amplitude of approximately $0.15 \mathrm{ppb}$. Strong correlations were observed with ethanal concentrations measured during NAMBLEX and the ratio of ethanal to formaldehyde determined by the gas chromatographic technique is in good agreement with previous measurements.

Some simple box modelling has been undertaken to investigate possible sources of formaldehyde. Such models are not able to predict absolute formaldehyde concentrations as they do not include transport processes, but the results show
\end{abstract}

Correspondence to: P. W. Seakins

(p.w.seakins@chem.leeds.ac.uk) that oxygenated VOCs such as ethanal and methanol are very significant sources of formaldehyde in the air masses reaching Mace Head.

\section{Introduction}

The North Atlantic Boundary Layer Experiment, NAMBLEX, took place at Mace Head, Eire, during July and August 2002 to help quantify our understanding of photochemical oxidation processes in clean and moderately polluted environments. Objectives included quantifying the role of halogen species in the marine boundary layer (MBL), studying the reactive nitrogen budget and formation of new particles. Objectives particularly relevant for our formaldehyde (HCHO), measurements included model/measurement comparisons for radical species and the role of reactive hydrocarbons in the MBL. Formaldehyde plays an important role in determining radical concentrations, influencing both $\mathrm{HO}_{\mathrm{x}}$ formation and removal. Due to its importance and difficulties in determining accurate concentrations (Gilpin et al., 1997) formaldehyde concentrations were measured using two different techniques. The University of Leeds (UoL) used a chromatographic method based on the detection of separated HCHO with a helium ionization detector (Hunter et al., 1998, 1999; Hopkins et al., 2003). The University of East Anglia, UEA, used a version of the Hantzsch reaction (Cardenas et al., 2000) where ambient HCHO was scrubbed into solutions and derivitized by reaction with 2,4 pentadione and ammonia. The adduct was then detected via fluorescence at $510 \mathrm{~nm}$ following UV excitation by a mercury lamp. The two systems were located at sites approximately $200 \mathrm{~m}$ apart.

Published by Copernicus GmbH on behalf of the European Geosciences Union. 
Table 1. Some previous measurements of formaldehyde in the marine environment.

\begin{tabular}{|c|c|c|c|c|c|c|}
\hline Reference & Campaign and Date & Location & Platform & Technique & $\begin{array}{l}{[\mathrm{HCHO}] \text { in }} \\
\text { clean air/pptv }\end{array}$ & Notes \\
\hline Harris et al. (1992) & "Polarstern" 1988 & North Atlantic & Ship & TDLS & 650 & $\begin{array}{l}\text { Measurement is mean } \\
\text { value over } 40-45^{\circ} \mathrm{N} \text {. } \\
\text { No diurnal variation }\end{array}$ \\
\hline Tanner et al. (1996) & NARE 1993 & Nova Scotia & Coastal site & DNPH & $200-400$ & $\begin{array}{l}\text { Summer measure- } \\
\text { ment }\end{array}$ \\
\hline Solberg et al. (1996) & EMEP 1994-5 & Mace Head & Coastal site & DNPH & $200-500$ & $\begin{array}{l}\text { Winter measurement. } \\
\text { Measurements at } \\
\text { other sites show } \\
\text { summer maxima. }\end{array}$ \\
\hline Cardenas et al. (2000) & ACSOE 1996 & Mace Head & Coastal site & Hantzsch & $200-450$ & $\begin{array}{l}\text { Summer measure- } \\
\text { ment. }\end{array}$ \\
\hline Weller et al. (2000) & ALBATROSS 1996 & North Atlantic & Ship & Hantzsch & $400-500$ & $\begin{array}{l}\text { No diurnal variation } \\
\text { observed. }\end{array}$ \\
\hline Fried et al. (2002) & NARE 1997 & Newfoundland & Plane & TDLS & $410 \pm 150$ & \\
\hline Wagner et al. (2001) & INDOEX 1999 & Indian Ocean & Ship & TDLS & $430 \pm 100$ & $\begin{array}{l}\text { Diurnal variation } \\
\text { with amplitude of } \\
\sim 200 \text { pptv observed. }\end{array}$ \\
\hline
\end{tabular}

In the very remote environment, methane is the major source of formaldehyde via the reactions:

$$
\begin{aligned}
& \mathrm{OH}+\mathrm{CH}_{4} \stackrel{\mathrm{O}_{2}}{\rightarrow} \mathrm{H}_{2} \mathrm{O}+\mathrm{CH}_{3} \mathrm{O}_{2} \\
& \mathrm{CH}_{3} \mathrm{O}_{2}+\mathrm{HO}_{2} \rightarrow \mathrm{CH}_{3} \mathrm{OOH}+\mathrm{O}_{2} \\
& \mathrm{CH}_{3} \mathrm{O}_{2}+\mathrm{CH}_{3} \mathrm{O}_{2} \rightarrow 2 \mathrm{CH}_{3} \mathrm{O}+\mathrm{O}_{2} \\
& \mathrm{CH}_{3} \mathrm{O}_{2}+\mathrm{CH}_{3} \mathrm{O}_{2} \rightarrow \mathrm{HCHO}+\mathrm{CH}_{3} \mathrm{OH}+\mathrm{O}_{2} \\
& \mathrm{CH}_{3} \mathrm{OOH}+h v \rightarrow \mathrm{CH}_{3} \mathrm{O}+\mathrm{OH} \\
& \mathrm{OH}+\mathrm{CH}{ }_{3} \mathrm{OOH} \rightarrow \mathrm{HCHO}_{2} \mathrm{H}_{2} \mathrm{O}+\mathrm{OH} \\
& \mathrm{OH}+\mathrm{CH}_{3} \mathrm{OOH} \rightarrow \mathrm{CH}_{3} \mathrm{O}_{2}+\mathrm{H}_{2} \mathrm{O} \\
& \mathrm{CH} \mathrm{O}+\mathrm{O}_{2} \rightarrow \mathrm{HO}_{2}+\mathrm{HCHO}^{\mathrm{O}}
\end{aligned}
$$

Under such low $\mathrm{NO}_{\mathrm{x}}$ conditions, the methyl peroxy radical $\left(\mathrm{CH}_{3} \mathrm{O}_{2}\right)$ formed from the reaction of $\mathrm{OH}$ with $\mathrm{CH}_{4}$ predominantly reacts with other peroxy radicals. Reaction with $\mathrm{HO}_{2}$ leads to $\mathrm{CH}_{3} \mathrm{OOH}$ which effectively acts as a reservoir species on route to $\mathrm{HCHO}$ formation (although it can be rained out). Self reaction leads more directly to $\mathrm{HCHO}$ formation. Reaction (R8) is very rapid and other reactions of methoxy radicals do not need to be considered. Additional sources of formaldehyde include higher hydrocarbons and oxygenated VOCs such as methanol or acetaldehyde.

In the presence of sufficient $\mathrm{NO}, \mathrm{CH}_{3} \mathrm{O}_{2}$ radicals react directly with $\mathrm{NO}$ to form methoxy radicals and subsequently formaldehyde via Reaction (R8).

$$
\mathrm{CH}_{3} \mathrm{O}_{2}+\mathrm{NO} \rightarrow \mathrm{CH}_{3} \mathrm{O}+\mathrm{NO}_{2}
$$

In a modelling study of formaldehyde production in the remote Indian Ocean, Wagner et al. (2002) showed that in the presence of only 2 pptv of $\mathrm{NO}$ approximately $50 \%$ of $\mathrm{CH}_{3} \mathrm{O}_{2}$ reacts via Reaction (R9).

There are two major chemical removal processes for formaldehyde. Firstly, reaction with $\mathrm{OH}$ (Reaction R10) which, via the subsequent rapid reaction of HCO with oxygen (Reaction $\mathrm{R} 11$ ), is a major route for conversion of $\mathrm{OH}$ to $\mathrm{HO}_{2}$.

$$
\begin{aligned}
\mathrm{OH}+\mathrm{HCHO} & \rightarrow \mathrm{H}_{2} \mathrm{O}+\mathrm{HCO} \\
\mathrm{HCO}+\mathrm{O}_{2} & \rightarrow \mathrm{HO}_{2}+\mathrm{CO}\left(\tau=4 \times 10^{-8} \mathrm{~s}\right)
\end{aligned}
$$

Secondly, photolysis, which can act as a significant free radical source. The efficiency of $\mathrm{HCHO}$ as a radical source depends on the branching ratio between the molecular and radical channels (Pope et al., 2005):

$$
\begin{aligned}
& \mathrm{HCHO}+h v \rightarrow \mathrm{H}_{2}+\mathrm{CO} \\
& \mathrm{HCHO}+h v \rightarrow \mathrm{H}+\mathrm{HCO}
\end{aligned}
$$

Formaldehyde, and carbonyls in general, have been shown to be major sources of $\mathrm{HO}_{\mathrm{x}}$ radicals in the urban winter atmosphere (Heard et al., 2004), but formaldehyde is also an important $\mathrm{HO}_{2}$ source in the remote free troposphere. Frost et al. noted that the importance of formaldehyde as a radical source will increase at higher, increasingly drier altitudes (Frost et al., 2002).

Table 1 lists some previous formaldehyde measurements in remote MBL environments, focusing particularly on studies in the North Atlantic environment. Measurements have been with a variety of techniques and from airborne, shipborne and coastal platforms. Average values range from 
200-1000 pptv. A seasonal dependence has been observed for formaldehyde measurements in the EMEP programme (Solberg et al., 1996) peaking during the summer months. There is conflicting evidence on meridional variations with measurements in the North Atlantic showing both positive and negative variations with increasing latitude (Harris et al., 1992; Weller et al., 2000). Fried and co-workers have carried out several airborne campaigns, their measurements show a general decrease in formaldehyde concentrations with altitude (Fried et al., 2002, 2003).

As can be seen from Table 1, a variety of experimental techniques have been deployed. Partially, this reflects the difficulties in making reliable measurements on this important atmospheric intermediate. The deployment of a variety of techniques has highlighted potential systematic errors in the measurement techniques. A good review of several techniques and the results of a field intercomparison can be found in the work by Gilpin et al. (1997) and very recently the results of an $\mathrm{HCHO}$ field (urban) intercomparison from the FORMAT programme have been published (Hak et al., 2005).

\section{Experimental}

\subsection{Site}

NAMBLEX took place at the Mace Head observatory on the west coast of Eire $\left(53^{\circ} 19^{\prime} 34^{\prime \prime} \mathrm{N}, 9^{\circ} 54^{\prime} 14^{\prime \prime} \mathrm{W}\right)$ during July and August 2002. A majority of formaldehyde measurements were taken between 1-21 August 2002. The location of the site is shown in Fig. 1. Air arriving between the angles of 180 and $300^{\circ}$ is free from any local land influence.

Five day back trajectories were calculated based on the wind field analysis produced by the European Centre of Medium Range Weather Forecasts (ECMWF) and were used to classify the origins of the air masses arriving at Mace Head. During the campaign local meteorological measurements were made by a wind profiler and its observations provided a record of the boundary layer structure, including measurements of average wind speed and direction (Norton et al., 2006). The local measurements suggest that for westerly winds, the ECMWF trajectories and local measurements are in good agreement. For north-easterly wind flows, characteristic of the early part of the campaign, local sea breezes dominated. However, the chemical signatures of typical anthropogenic pollutants such as $\mathrm{CO}$ and $\mathrm{C}_{2} \mathrm{H}_{2}$ suggest that the site is still receiving air broadly characteristic of origin of the air mass, albeit potentially moderated by local meteorology.

The inset to Fig. 1 shows the location of the two formaldehyde measurements. The UEA apparatus was co-located with a majority of the other instrumentation $\sim 100 \mathrm{~m}$ distant and at $\sim 10 \mathrm{~m}$ elevation from the average high tide mark. The UoL instrumentation was located a further $\sim 200 \mathrm{~m}$ inshore and elevated by a further $\sim 20 \mathrm{~m}$.

\subsection{UoL apparatus}

The UoL instrument used during the NAMBLEX campaign was based on a gas chromatographic (GC) system as described by Hopkins et al. (2003). The sampling inlet was placed $2 \mathrm{~m}$ above the ground and consisted of $\sim 12 \mathrm{~m} \mathrm{1/4}$ PFA tubing, and was pumped at a speed of $1 \mathrm{slm}$. The sample passed through a $6.4 \mathrm{ml}$ sample loop (Silco Steel). During injection, helium carrier gas (CP grade, BOC, $9 \mathrm{ml} \mathrm{min}^{-1}$, backing pressure $50 \mathrm{psi}$, further purified via passing through liquid nitrogen traps) was diverted through the loop, sweeping the sample onto the column $(50 \mathrm{~m}, 0.32 \mathrm{~mm}$ id, $100 \%$ dimethyl polysiloxane, WCOT column, $5 \mu \mathrm{m}$ phase thickness, CP-Sil 5CB Chrompack, Netherlands) and refocused at the head of the column in a liquid nitrogen trap. Following the elution of the untrapped air, the analytes were released and were separated in the column and detected using an argon doped (1\% Ar in $\mathrm{He}, \mathrm{BOC}, \mathrm{CP}$ grade), pulsed discharge helium ionisation detector (pdHID) (Model D4, VICI AG, Schenkon, Switzerland). The detector flow was $30 \mathrm{ml} \mathrm{min}^{-1}$ maintained with a calibrated restrictor. After the elution of formaldehyde the column flow was reversed and the column was back flushed $\left(30 \mathrm{ml} \mathrm{min}^{-1}, 70 \mathrm{~s}\right.$, backing pressure $60 \mathrm{psi}$ ) to prevent water reaching the detector or the build-up of heavier weight material on the column. The sample cycle time throughout the campaign was $5.5 \mathrm{~min}$.

The detection limit during the campaign was 42 pptv; this was calculated taking the minimum detectable peak to have a signal to noise ratio of $3: 1$. The system used a formaldehyde gas phase standards generator for calibration (KINTEK, LaMarque, TX). A permeation tube containing polymeric formaldehyde with a known emission rate at a set reference temperature $(333 \mathrm{~K})$ was held in a stabilized oven (temperature variation $< \pm 0.1 \mathrm{~K}$ ) flushed with a constant flow rate $(10.0 \mathrm{sccm})$ of UHP nitrogen. Delivery concentrations of 4$50 \mathrm{ppbv}$ (during campaign), or subsequently $2-50 \mathrm{ppbv}$ (with increased flow rate), were obtained by diluting the oven flow with additional known flow rates of UHP nitrogen. The delivery tube was connected to the GC sample inlet via a "tee" junction with a positive flow out of the vent, ensuring that the delivery pressure was at one atmosphere. The precision was attained from the standard deviation of replicate calibration factors and was calculated to be $3 \%$. The uncertainty was attained from the errors associated with the standards generator and was determined to be $9 \%(2 \sigma)$.

\subsection{UEA apparatus}

The fluorescence technique is based on the Hantzsch reaction which is a liquid phase reaction of formaldehyde followed by fluorescence detection of the resulting adduct. This technique requires formaldehyde to be transferred from the gas phase into liquid phase, achieved via a stripping solution of $0.1 \mathrm{~N} \mathrm{H}_{2} \mathrm{SO}_{4}$ (made up from ACS reagent grade $\mathrm{H}_{2} \mathrm{SO}_{4}$, Aldrich) at room temperature, which is pumped through a 


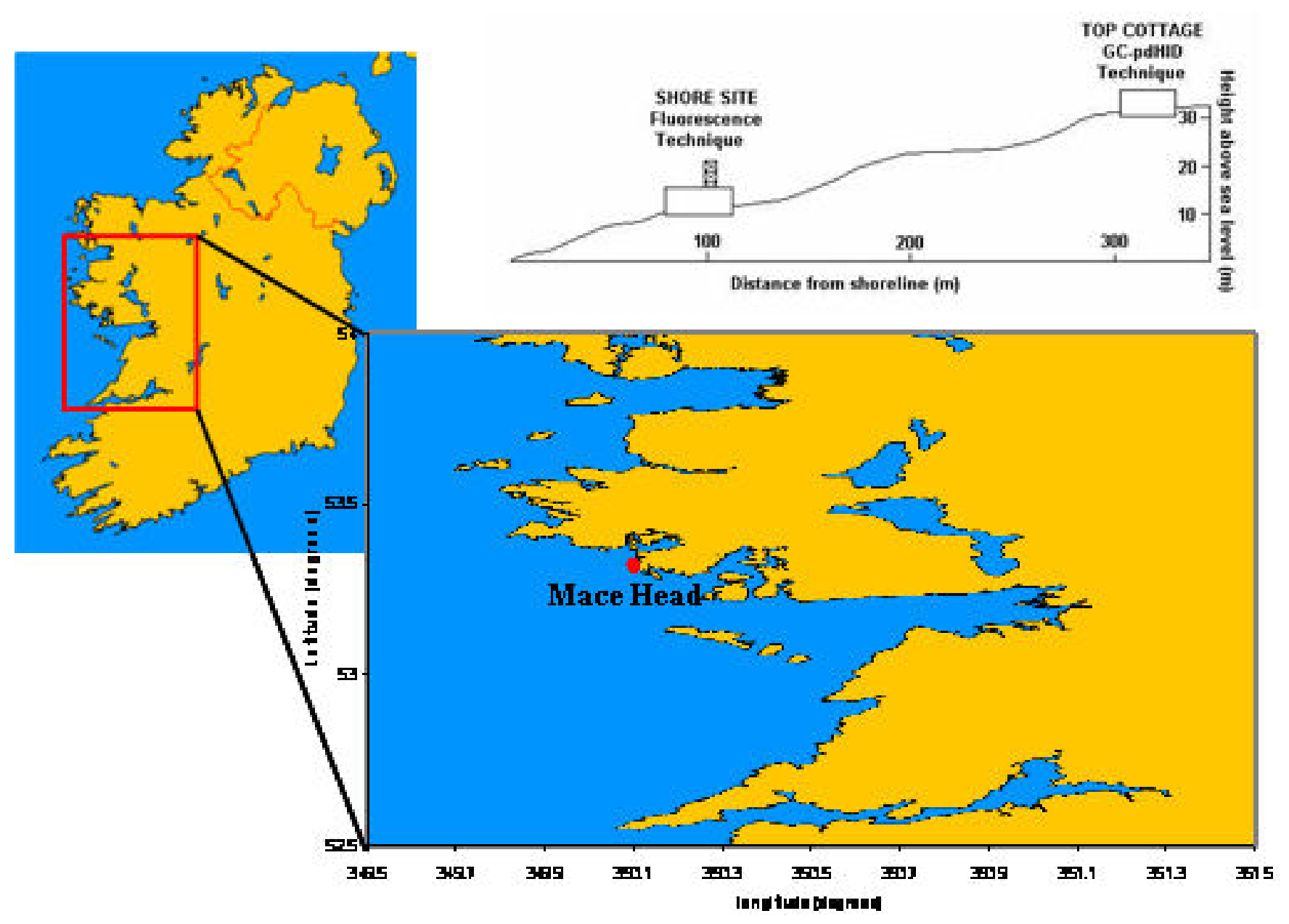

Fig. 1. Location of the Mace Head observatory and the relative positioning of the two formaldehyde instruments.

coil ( $45 \mathrm{~cm}$ long, 10 turns of $3 \mathrm{~mm}$ o.d. Pyrex) and forced into contact with gaseous formaldehyde. Ambient formaldehyde was sampled at a height of $\sim 5 \mathrm{~m}$ through approximately $10 \mathrm{~m}$ of $3 / 8^{\prime \prime}$ PFA tubing. The pumping speed was a total of $15 \mathrm{slm}$ giving a very short residence time in the sampling line, and only small decrease in pressure in the sample line. The sample was introduced into the instrument at $1.5 \mathrm{slm}$ through a $1 \mathrm{~m}$ length of $1 / 4^{\prime \prime}$ PFA tubing.

The Hantzsch process is based on the liquid phase reaction of formaldehyde with acetylacetone (2,4 pentadione) and ammonia to produce diacetyldihydrolutidine, (DDL) that is excited at $412 \mathrm{~nm}$ (Hg-Phosphor $215 \mathrm{lamp}$, Jelight, USA) and the fluorescence is detected at $510 \mathrm{~nm}$ with a photomultiplier tube (Hamamatsu).

The detection limit for this instrument was in the region of 50 pptv (Cardenas et al., 2000). The instrument was also calibrated using a permeation source (KIN-TEK LaMarque, TX). The calibrant introduced into the instrument via a "Teepiece" to vent the excess and ensure the calibration was delivered at atmospheric pressure. The mean precision and accuracy of the instrument (based on zero noise, calibra- tion uncertainties and stripping efficiency uncertainties) were $\pm 6.3 \%$ and $\pm 13.2 \%$, respectively with a minimum uncertainty of \pm 25 pptv. The detection limit (three sigma of zero noise) of the instrument varied between 38 and 69 pptv during the campaign. Zeros were performed every $5 \mathrm{~h}$ by scrubbing the sample with a charcoal filter.

\subsection{Intercomparisons and artefacts}

During the campaign the calibration sources for both instruments were exchanged and compared. When used on the UoL instrument, the UEA calibration source produced values within $2 \%$ of those generated using the UoL source. It was therefore concluded that the calibration sources were in good agreement for the campaign period.

The two instruments also took part in a laboratory intercomparison at the National Physical Laboratories (Teddington, UK) during June 2003. In these experiments all the instruments sampled from a common chamber (NPL Standard Atmosphere Generator). HCHO concentrations in the chamber were calculated from permeation rates of a known 


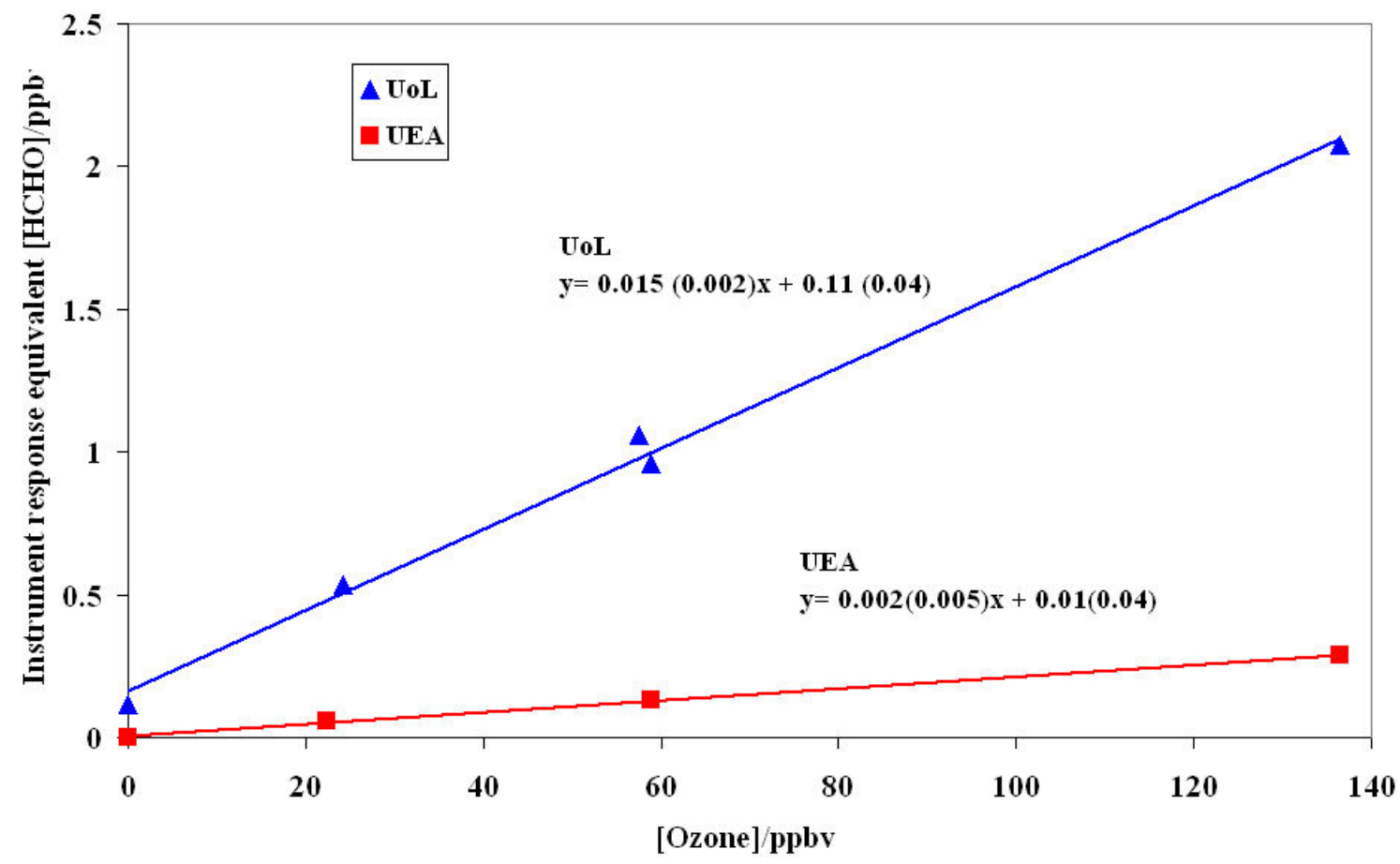

Fig. 2. Ozone artefact for ( $\boldsymbol{\Lambda})$ UoL apparatus, (ם) UEA apparatus as determined during experiments at NPL, 2003.

standard and measured dilution flows. All the instruments performed linearity and stability checks and a blind sampling. Various concentrations of ozone were generated and introduced into the chamber to investigate possible artefacts.

Both the instruments responded well to the linearity (2$8 \mathrm{ppbv}$ ) and stability experiments (apparatus run overnight at $0.5 \mathrm{ppbv}$ ) and reported results within experimental errors for the blind testing, although the concentration, at $\sim 7 \mathrm{ppbv}$, was significantly higher than ambient concentrations in the MBL. Both instruments showed a positive interference for ozone as shown in Fig. 2.

The magnitude of the ozone artefact on the UoL instrument was significantly greater, but was reproducible, both at NPL and during subsequent experiments at Leeds. The results reported below for both instruments have been corrected for ozone measurements as recorded at Mace Head by the FAGE group using a UV photometric analyser.

\section{Results}

3.1 Comparison of time series from UoL and UEA measurements

Figure 3 shows the formaldehyde time series for both instruments. Two observations are immediately apparent. Firstly, the results from the UoL are significantly higher, and outside the combined random errors of both techniques (9\% for UoL and $13 \%$ for UEA based on errors associated with the calibration processes). Secondly there is a reasonable correlation between the two measurements, and in some cases, for example that shown in the inset to Fig. 3, the pattern of variation is almost identical.

Figure 4 shows a correlation plot of the results. There is significant scatter in the data which may be associated with sampling slightly different air masses either due to local meteorology or to differences in the sampling techniques. The UoL apparatus is essentially a grab sample taken every $5.5 \mathrm{~min}$, whereas UEA data are based on averaging over a one minute period. The difference in the UoL and UEA data appears to be in an offset rather than in the gradient of the correlation plot.

Given the good agreement on the trends in formaldehyde concentrations, possible reasons the systematic error include; sample losses in the lines or scrubbing processes, calibration errors, interferences from other gases and significant blanks in the UoL apparatus.

The University of Leeds measurements showed no variation with the length of sampling tube in either field or laboratory tests. Given that the same material was used for sampling in the UEA apparatus, we would not expect any significant losses in that system either. Significant loss processes in the UEA instrument would be very surprising since the whole wetted path of the sample is PFA and no loss processes on PFA have been seen in numerous laboratory tests. The difference in pressure between the sample drawn down the $3 / 8^{\prime \prime}$ PFA and the calibrant delivered directly into the instrument is at most $10 \%$. Both losses and differences in pressure 


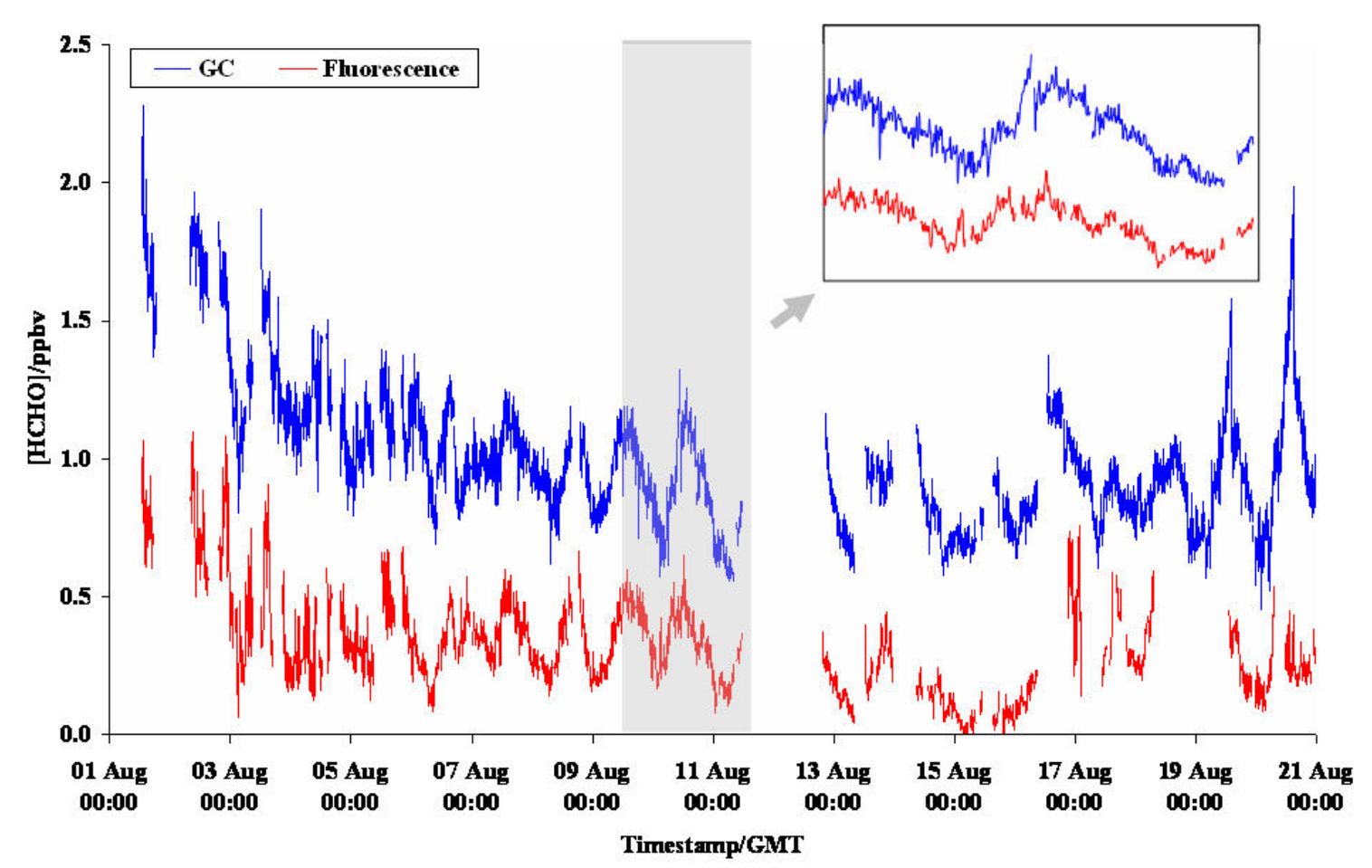

Fig. 3. Time series of formaldehyde concentrations from GC and fluorescence techniques. All data corrected for ozone interferences.

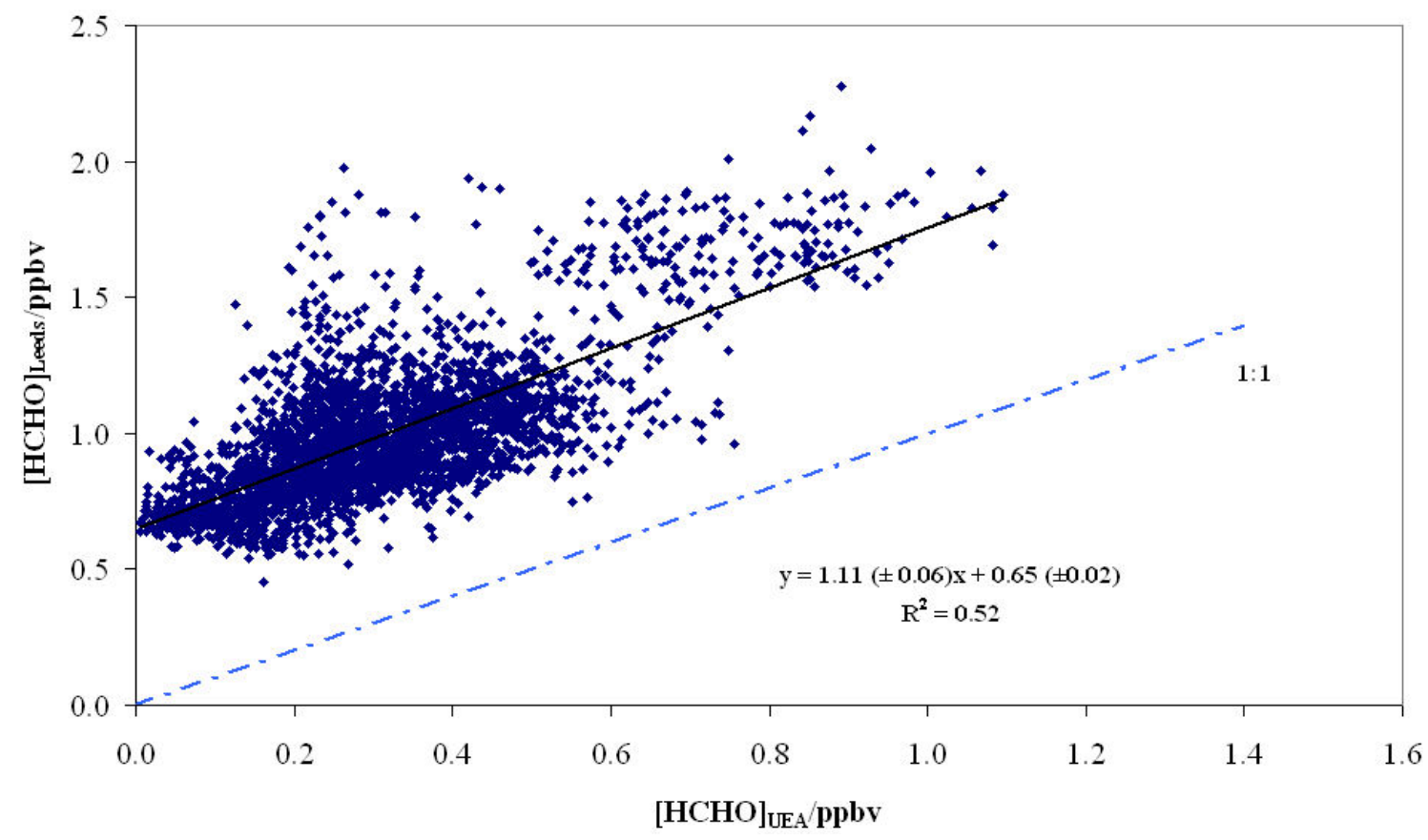

Fig. 4. A graph showing the weighted bivariant regression between the GC and the fluorescence technique for all data (solid line), and the $1: 1$ line (dotted line).

would lead to an underestimation of HCHO, but would be expected to show a difference in slope rather than an offset in the scatter plot.
In general, calibration errors do not appear to be a problem as the calibration systems were compared during the campaign. The UEA system requires transfer from the gas to 
Table 2. Summary of UoL and UEA formaldehyde concentrations for the various air masses encountered during NAMBLEX.

\begin{tabular}{lllll}
\hline Air Mass Origin & $\begin{array}{l}\text { UoL } \\
24 \mathrm{~h} \text { average } \\
{[\mathrm{HCHO}] / \mathrm{ppbv}}\end{array}$ & Range/ppbv & $\begin{array}{l}\text { UEA } \\
24 \mathrm{~h} \text { average } \\
{[\mathrm{HCHO}] / \mathrm{ppbv}}\end{array}$ & Range/ppbv \\
\hline Continental & $1.20 \pm 0.13$ & $0.98-1.58$ & $0.37 \pm 0.11$ & $0.13-0.73$ \\
Westerly & $0.96 \pm 0.09$ & $0.78-1.15$ & $0.27 \pm 0.07$ & $0.13-0.43$ \\
Anticyclonic & $0.92 \pm 0.15$ & $0.72-1.31$ & & \\
\hline
\end{tabular}

liquid phase. This process is always highly efficient, but is slightly temperature dependent (92-98\% as temperature decreases from $298-278 \mathrm{~K})$. The temperature of the laboratory fluctuated by $\pm 5 \mathrm{~K}$ and variations in sampling versus calibration temperature are an additional small source of error.

As described in the previous section ozone artefacts were detected in both systems and the reported data have been suitably corrected. Corrections were typically of the order of 300-400 pptv formaldehyde. One other possible artefact particularly relevant to the MBL is the presence of water vapour. Tests performed at NPL were inconclusive and further work is planned. It should be noted that there was no systematic variation in the offset with relative humidity. Blanks were recorded on a daily basis for the UoL apparatus. These were obtained by attaching a cylinder of zero nitrogen (Premier Grade, Air Products) via 1/4" Teflon tubing to the inlet port of the GC. A "tee" junction was placed upstream of the sample inlet to restrict the upstream pressure to 1 atmosphere. The zero air was drawn into the GC via the pump in the normal way. An ozone artefact for the UoL apparatus has already been described. It should be noted that blank measurements were made with dry gas, our planned work on humidity effects may determine whether this is an important issue. We cannot rule out the possibility of other undetected artefacts.

Obviously one, or both, instruments were subject to systematic errors during NAMBLEX, but either these had been rectified by the following summer, or are only apparent during real air, rather than laboratory sampling. We are therefore at a loss to explain the differences in measured concentrations at Mace Head during NAMBLEX and in the following section the results of each apparatus are presented separately. The measurements are compared with other measurements and various models in the discussion section.

\subsection{Average values and diurnal profiles for UoL apparatus}

The campaign can broadly be divided into three different air masses. From 1-5 August the site experience continental air masses which had originated in Scandinavia and had passed over northern England. This was followed by a long period (6-17 August) of relatively long trajectories (high wind speeds) with a significant westerly component (rang- ing from south to north westerly). It is possible to further subdivide this period into air masses with $\mathrm{NW}, \mathrm{W}$, and $\mathrm{SW}$ origins, however, analysis showed no significant variation in formaldehyde concentrations with these finer components and hence all westerlies are considered together. Over the last few days of the formaldehyde campaign the wind was still westerly but from an anticyclonic weather system with low wind speeds. Summaries of the formaldehyde concentrations for each period can be found in Table 2 .

Not surprisingly, formaldehyde concentrations were highest during the initial continental air flow. Concentrations of hydrocarbons and $\mathrm{CO}$ are also elevated during this period. Thereafter, concentrations decreased and a diurnal pattern became more apparent, Fig. 5a, with concentrations during the westerly air flows varying from an early morning (03:00-05:30 GMT) minimum of $~ 850$ pptv to a peak value of $\sim 1050$ pptv between 14:00-16:00 GMT (local time is GMT+1). During the latter part of the anticyclonic westerly airflows, the amplitude of the diurnal profile appeared to increase. There were also concurrent increases in acetylene concentrations suggesting some local contamination during these periods.

\subsection{Average values and diurnal profiles from UEA}

Results from the fluorescence apparatus show generally similar behaviour. Concentrations are elevated at the start of the campaign, but appear to remain constant between 200500 pptv from the 3-14 August. As with the UoL data for the westerly winds, a pronounced diurnal variation is observed, as shown in Fig. 5b, with an amplitude similar to that observed by the UoL.

The concentrations measured on 15 August are significantly lower than other periods during the westerly airflow with values between 50-100 pptv. After the 16 August data from the UEA apparatus became patchy due to intermittent lamp failure. 


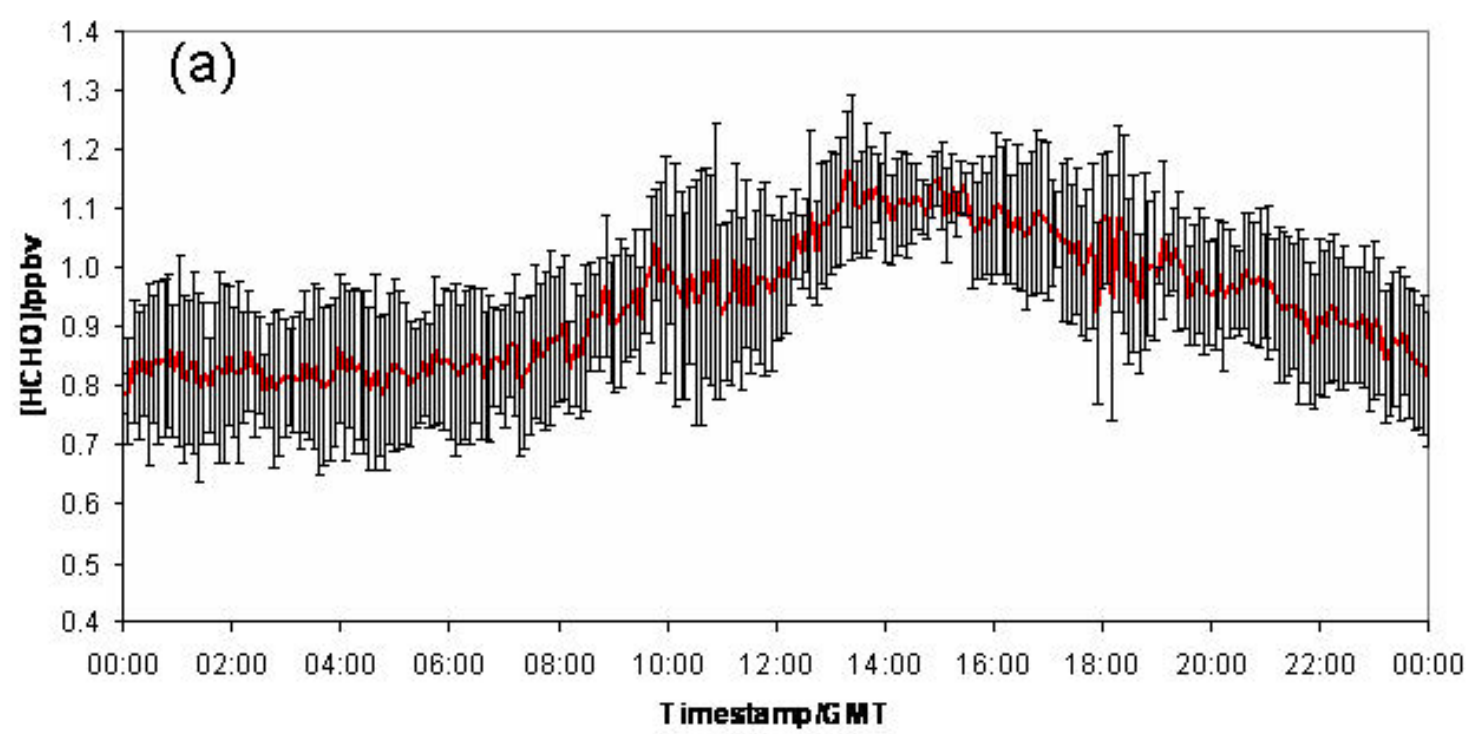

Fig. 5a. Diurnal variation of formaldehyde concentrations as measured by UoL during westerly airflows (6-17 August 2002). Error bars represent one standard deviation of concentrations at that particular timestamp.

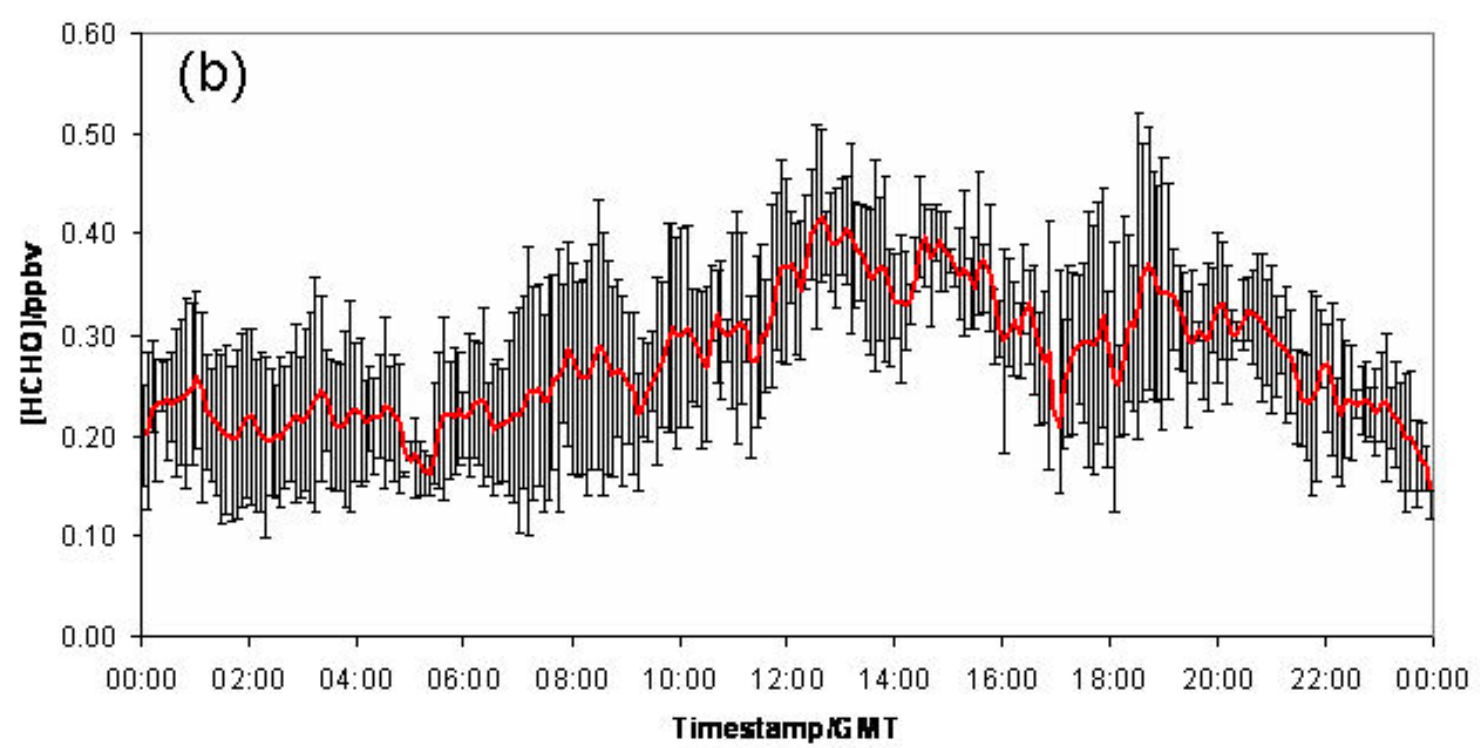

Fig. 5b. Diurnal variation of formaldehyde concentrations as measured by UEA during westerly airflows (6-16 August 2002). Error bars represent one standard deviation of concentrations at that particular timestamp.

\section{Discussion}

4.1 Comparison with previous marine boundary layer measurements

Some results from previous campaigns are presented in Table 1 . We have focused predominantly on measurements from the North Atlantic although some other campaigns are included.
Formaldehyde measurements at Mace Head are relatively limited. A measurement campaign was conducted at Mace Head under the EMEP programme, with formaldehyde being monitored from November to April using 2,4 DNPH cartridges with subsequent off-line analysis by HPLC (Solberg et al., 1996). Samples were collected twice weekly, each measurement consisting of $8 \mathrm{~h}$ sampling centred around midday, with subsequent off line analysis at NILU. Solberg et al. reported monthly averages between 200-500 pptv over 
this winter period. Direct comparison with our summer data cannot be made, however, the winter concentrations appear to correlate well with those made at a Norwegian site (Birkenes), where summer concentrations reach almost 1 ppbv. Solberg et al. report annual variations in formaldehyde levels from a number of rural sites around Europe and all show summer maxima.

Formaldehyde was measured at Mace Head during the ACSOE 96 and 97 campaigns. A majority of the measurements were made using an earlier version of the fluorometric technique, and a more limited data set was also recorded using tuneable diode laser spectroscopy (TDLS) (Cardenas et al., 2000). Typical values for westerly air masses were 200-400 pptv from the fluorometric technique, whereas the TDLS produced higher, but scattered values with a range of 0-1000 pptv.

A number of formaldehyde measurements were made during the North Atlantic Regional Experiment (NARE) campaigns. During NARE 1993, Tanner et al. (1996) measured a range of carbonyl compounds using derivatization via 2,4 DNPH/HPLC at Cherbourg Point, Nova Scotia. Typical values for clean air at 200-400 pptv are in good agreement with the UEA data. Measurements were only made every six hours, so no diurnal trends are reported. Tanner et al. report a relationship between formaldehyde and ethanal with the latter being approximately $50 \%$ of the formaldehyde concentrations. This observation will be discussed further below.

During NARE 1997 a number of airborne measurements were made from St John's, Newfoundland, using both TDLS and the coil/DNPH technique (Fried et al., 2002). Generally the agreement between the two techniques was good with a gradient on the scatter plot of $0.98 \pm 0.07$, however, approximately $30 \%$ of the data points lay outside the combined $2 \sigma$ uncertainties. Median values in clean background air from $0-2 \mathrm{~km}$, between $35-55^{\circ} \mathrm{N}$ are $400 \mathrm{pptv}$ for TDLS (range 300-900 pptv for lowest altitude measurements) and 410 pptv for the CDNPH (range 200-800 pptv for lowest altitude measurements). Average concentrations decrease with both altitude and latitude.

Two shipborne campaigns have monitored formaldehyde in the North Atlantic. The ALBATROSS campaign took place during October and November 1996 with the cruise being a meridional track from $60^{\circ} \mathrm{N}$ to $45^{\circ} \mathrm{S}$. Formaldehyde was monitored via a commercial apparatus based on the Hantzsch reaction (Weller et al., 2000). A variety of different air masses were encountered. Typical concentrations when the ship was between $20-40^{\circ} \mathrm{N}$ and intercepting trajectories similar to the westerlies and south- westerlies reaching Mace Head were in the region of 300-800 pptv. Harris et al. (1992) report data from the 1988 "Polar Stern" cruise which took place during September and October from $45^{\circ} \mathrm{N}$ into the southern hemisphere. Formaldehyde was predominantly measured using TDLS with a small number of comparative experiments obtained with DNPH sampling and subsequent analysis via HPLC. The two methods were in good agreement. Harris et al. report a mean formaldehyde concentration between $40-45^{\circ} \mathrm{N}$ of $650 \mathrm{pptv}$, with concentrations decreasing slightly during the cruise south.

When used to compare with formaldehyde concentrations at Mace Head, the results of other campaigns need to be interpreted carefully. For air and shipborne measurements variation with latitude will be strongly dependent on the origins of the air mass reaching the receptor at that point and may not be typical of longer term measurements at that latitude. Both Fried et al. (2002) and Weller et al. (2000) report a decrease in average formaldehyde concentrations with latitude, however, because the air masses trajectories and ocean currents vary across the region, this does not mean that the latitudinal variation will be the same over the eastern Atlantic. Finally, the EMEP data showed significant annual variation in formaldehyde concentrations (as would be expected from a photochemical intermediate) and therefore results from different seasons should be interpreted with care.

The final campaign discussed in this section took place in the Indian Ocean during spring 1999 (Wagner et al., 2001). Given the location, comparison with Mace Head concentrations are difficult, however, results from the INDOEX campaign, (where formaldehyde was measured by TDLS) are interesting for several reasons. Firstly, even for trajectories that had been over the open ocean for seven days, and hence lost any continental formaldehyde, concentrations were still significant ( $\sim 500 \mathrm{pptv})$. A direct oceanic source is not expected and therefore this is good evidence of significant $\mathrm{HCHO}$ production from long-lived precursors, including oxygenated VOC. Secondly, a strong positive correlation was noted with $\mathrm{CO}$ for a variety of air masses including very aged air $\left(\mathrm{HCHO} / \mathrm{CO} \approx 3 \times 10^{-3}\right.$ ). Finally, during periods of consistent air flow, diurnal variations in [HCHO] were observed with an amplitude of approximately $200 \mathrm{pptv}$ in the northern hemisphere, consistent with the observed amplitudes of both UEA and UoL instruments during clean westerly airflows.

\subsection{Comparison with other NAMBLEX measurements}

The NAMBLEX campaign was characterised by relatively polluted air during the first part of the campaign, with a period of consistent, strong, westerly, clean air and finally anticyclonic conditions, originating in the North Atlantic. Anthropogenic pollutants are therefore expected to be high during the initial part of the campaign, and thereafter relatively low, although the low wind speeds under anticyclonic conditions may allow for influence by local sources. The acetylene and $\mathrm{CO}$ concentrations shown in Fig. 6 broadly match the expected behaviour.

If the correlation between formaldehyde and $\mathrm{CO}$, observed during the INDOEX campaign by Wagner et al. (2001) applied under NAMBLEX conditions, then formaldehyde concentrations during westerly airflows would be predicted to be in the region of 200-300 pptv, in good agreement with the 


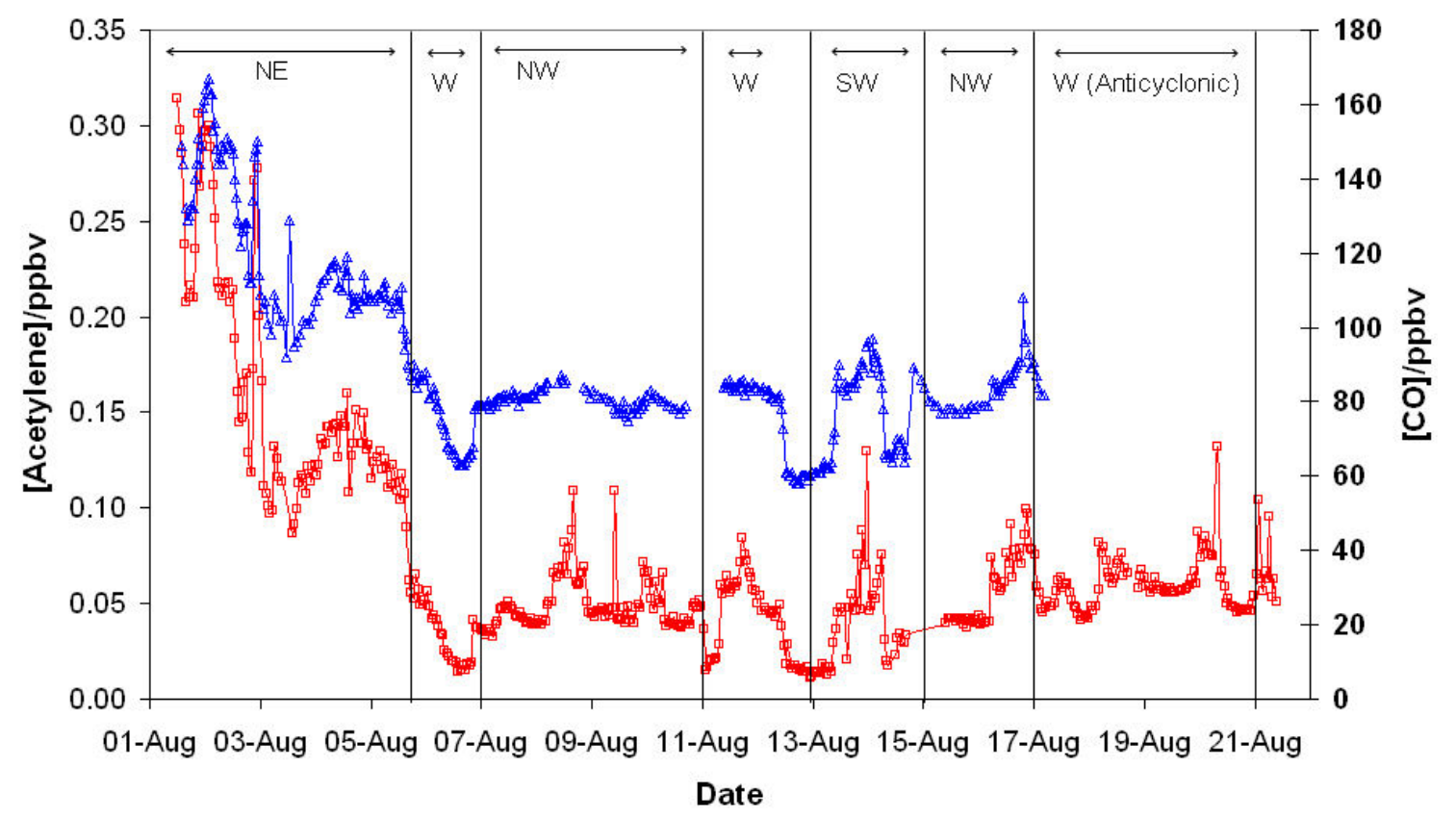

$\square$ Acetylene $\triangle \mathrm{CO}$

Fig. 6. Signatures of anthropogenic tracers. Acetylene and CO data were provided by the University of York and Mace Head research station, respectively.

UEA data. However, Fig. 6 shows a strong correlation between $\mathrm{CO}$ and acetylene, a primary pollutant. Therefore $\mathrm{CO}$ concentrations at Mace Head may correlate more strongly with primary sources rather than photochemical production and the relationship between formaldehyde and $\mathrm{CO}$ observed during highly aged air in the Indian Ocean may not apply.

Methane levels are likely to be slightly elevated in polluted air masses, but formaldehyde is also formed during the atmospheric oxidation of virtually all higher hydrocarbons and oxygenated VOCs (OVOC), and due to their higher photochemical loss rates, these latter species are likely to be the dominant influence on formaldehyde concentrations.

A good example of a formaldehyde precursor is acetaldehyde (ethanal). Both photolysis and reaction with $\mathrm{OH}$ can lead to formaldehyde formation:

$$
\begin{aligned}
& \mathrm{CH}_{3} \mathrm{CHO}+h v \stackrel{\mathrm{O}_{2}}{\longrightarrow} \mathrm{CH}_{3} \mathrm{O}_{2}+\mathrm{CO}+\mathrm{HO}_{2} \\
& \mathrm{OH}+\mathrm{CH}_{3} \mathrm{CHO} \stackrel{\mathrm{O}_{2}}{\longrightarrow} \mathrm{CH}_{3} \mathrm{C}(\mathrm{O}) \mathrm{O}_{2}+\mathrm{H}_{2} \mathrm{O} \\
& \mathrm{CH}_{3} \mathrm{C}(\mathrm{O}) \mathrm{O}_{2}+\mathrm{RO}_{2} \rightarrow \mathrm{CH}_{3}+\mathrm{CO}_{2}+\text { products }
\end{aligned}
$$

Figure 7a shows a comparison of the time series for acetaldehyde and formaldehyde, with Fig. 7b showing the corresponding correlation plots with the UoL data. Acetaldehyde was measured by the University of York (Hopkins et al., 2003; Lewis et al., 2005) concentrating VOC and OVOC from $\sim 11$ of air onto a solid trap followed by rapid thermal desorption, separation via GC with detection by FID. The general correlation between the $\mathrm{CH}_{3} \mathrm{CHO}$ and $\mathrm{H}_{2} \mathrm{CO}$ data from the UoL is good with both showing the same gradual decline in concentrations at the beginning of the campaign, followed by consistent and relatively low levels during the periods of westerly air flow.

The correlation plot of acetaldehyde concentrations with the UoL formaldehyde data $\left([\mathrm{HCHO}]=(1.25 \pm 0.29)\left[\mathrm{CH}_{3} \mathrm{CHO}\right]+0.46 \pm 0.19\right) \quad$ shows an intercept of $0.46 \mathrm{ppbv}$ on the $\mathrm{HCHO}$ axis. An intercept would be expected given that a significant fraction of formaldehyde will be formed from methane or from fragmentation processes that by-pass acetaldehyde production.

A significant positive correlation between formaldehyde and acetaldehyde was observed by Tanner et al. (1996) during measurements at a coastal site in Nova Scotia during NARE 1993. They reported $[\mathrm{HCHO}]_{\mathrm{ppbv}}=1.9\left[\mathrm{CH}_{3} \mathrm{CHO}\right]_{\mathrm{ppbv}}+0.22$ with an $r$ coefficient of 0.62. Errors on the gradient and intercept are not reported, but from the scatter of the plot, are likely to be at least $\pm 33 \%$ and therefore comparable with our parameters derived observations between acetaldehyde and the UoL formaldehyde data. Monthly averaged formaldehyde and acetaldehyde concentrations were reported by Solberg et al. (1996) from a number of remote European sites including Mace Head. In all cases formaldehyde concentrations were greater than acetaldehyde, typically about a factor of two during the summer months.

The UEA formaldehyde concentrations are comparable in value with the measured acetaldehyde concentrations. Given 


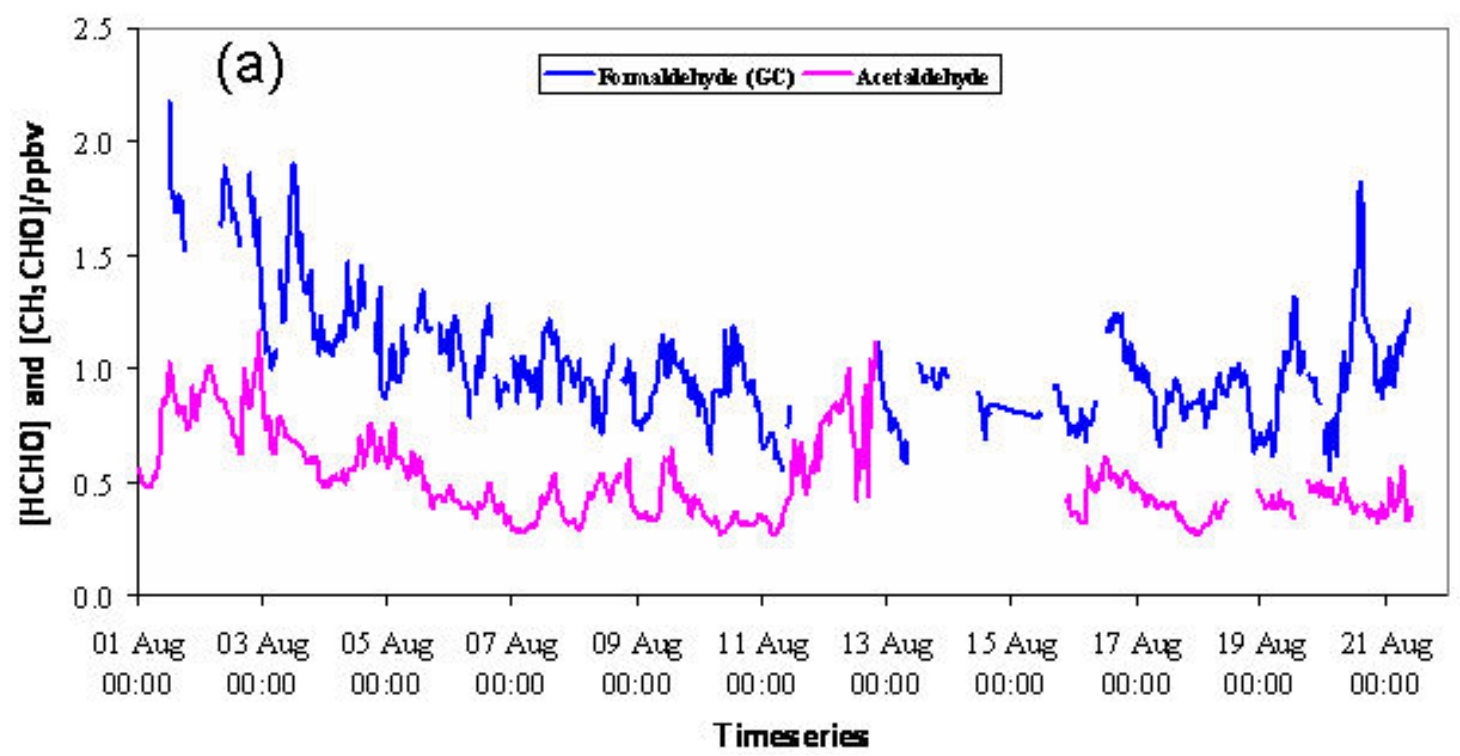

Fig. 7a. Time matched series of formaldehyde (UoL) and acetaldehyde (University of York).

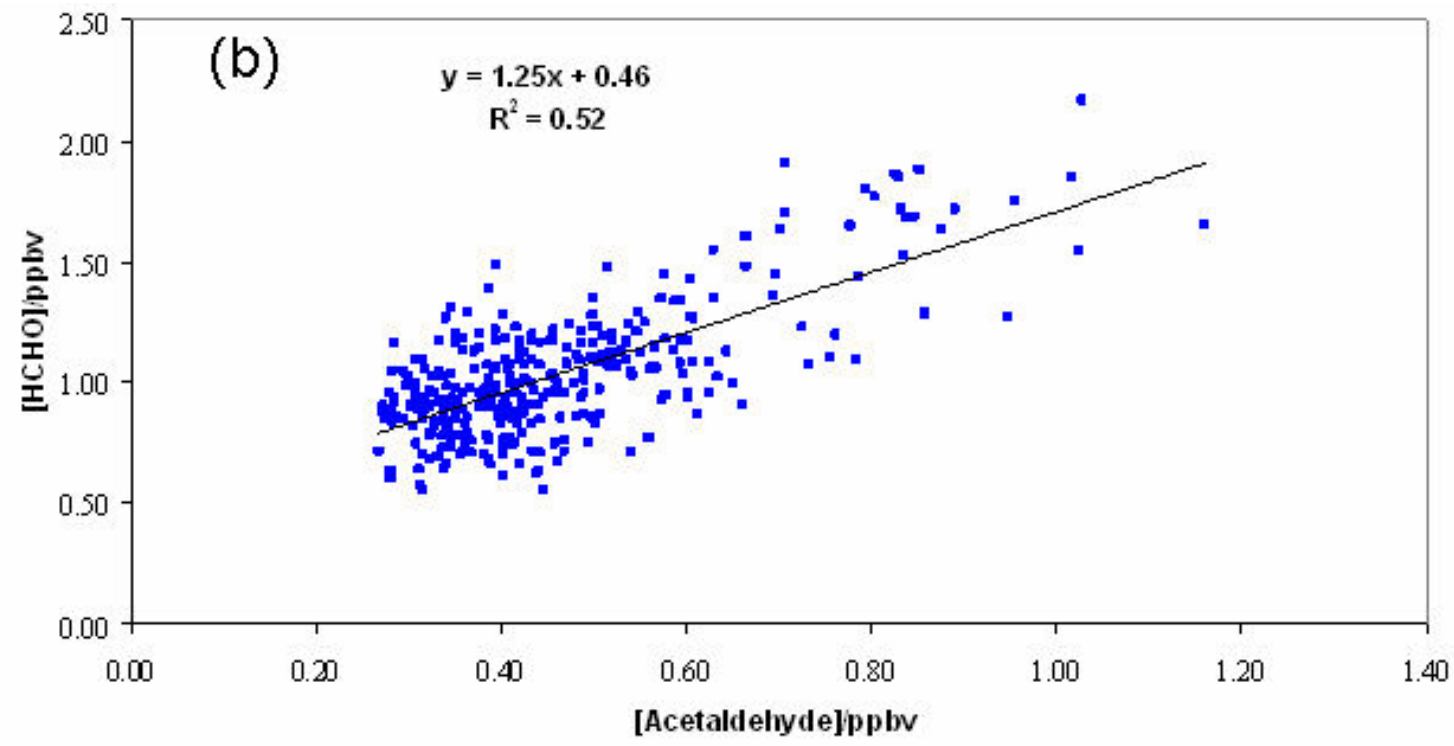

Fig. 7b. Correlation plot of UoL formaldehyde vs. acetaldehyde. The regression equation is $[\mathrm{HCHO}]=1.25( \pm 0.07) \times\left[\mathrm{CH} \mathrm{CHO}_{3}\right.$ $+0.46( \pm 0.03)$, where the errors are $1 \sigma$.

our current understanding of formaldehyde and acetaldehyde photo oxidation these observations appear to be incompatible.

Methanol is another significant OVOC precursor for formaldehyde. Reaction with $\mathrm{OH}$ leads to $\mathrm{HCHO}$ via reaction of either $\mathrm{CH}_{3} \mathrm{O}$ isomer formed by the initial abstraction reaction. In the MBL reaction of $\mathrm{Cl}$ atoms with hydrocarbons and OVOCs may also need to be considered (Ramacher et al., 1999). Cl initiated reactions tend to be less selective in the position of abstraction, but in gen- eral form the same type of radicals as $\mathrm{OH}$ initiation. $\mathrm{Al}$ though concentrations of $\mathrm{Cl}$ atoms are much lower than $\mathrm{OH}$ in the MBL (typically $5 \times 10^{3} \mathrm{~cm}^{-3}$ vs. $1 \times 10^{6} \mathrm{~cm}^{-3}$ ), the magnitude of the abstraction rate coefficients (typically $>5 \times 10^{-11} \mathrm{~cm}^{3}$ molecule ${ }^{-1} \mathrm{~s}^{-1}$ (Qian et al., 2002; Seakins et al., 2004)) is such that $\mathrm{Cl}$ initiated chemistry can be significant. 


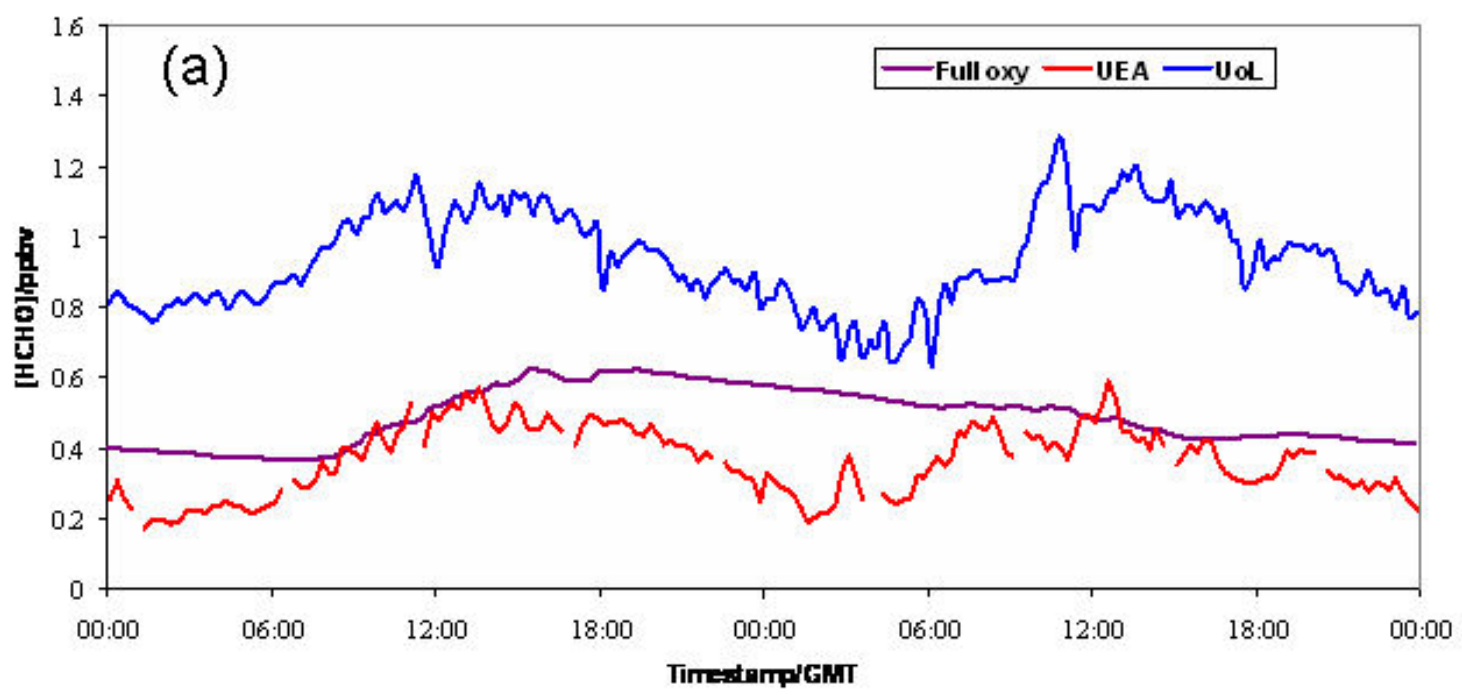

Fig. 8a. Comparison of measured and modelled formaldehyde for 9-10 August 2002 (JD221-222).

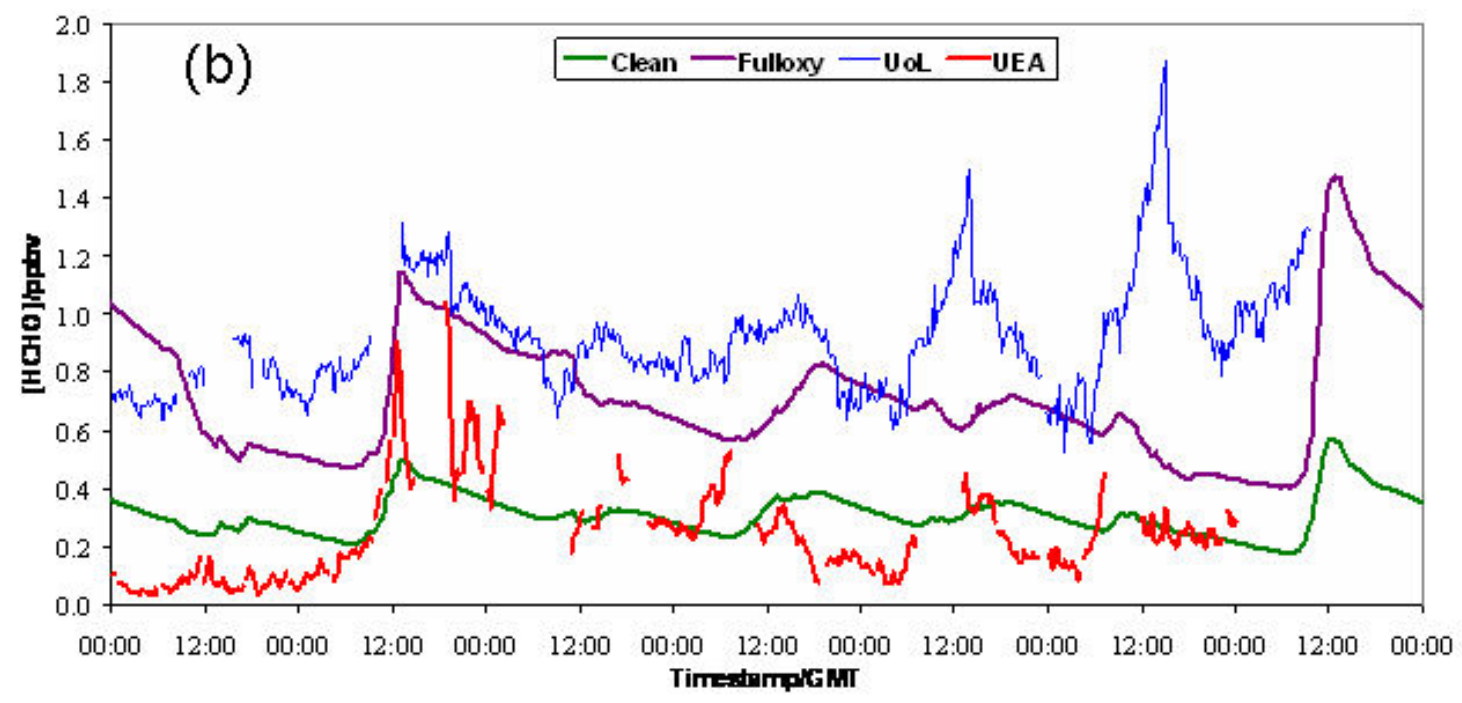

Fig. 8b. Comparison of measured and modelled formaldehyde for 15-21 August 2002 (JD227-233).

\subsection{Modelling}

The simplicity of the chemistry in the MBL allows for the construction of relatively simple models to test our understanding of photochemistry in this environment. The ideal molecules for comparison are those with very short lifetimes, so that transport can be ignored and realistic comparisons can be made with box models. Hydroxyl and hydroperoxy radicals are ideal examples and comparisons between model predictions and measurements have been made in a number of environments, including the marine boundary layer (Carslaw et al., 2002; Heard et al., 2004; Sommariva et al., 2004). The lifetime of formaldehyde (typically $\sim 4 \mathrm{~h}$ under midday conditions) is such that transport should really be considered, however, zero dimensional box models give an indication of the expected concentrations from various chemical schemes and highlight the relative importance of various formation and removal channels. A good example of a box model is described by Wagner et al. $(2001,2002)$ and used to interpret shipborne measurements in the remote Indian Ocean from the INDOEX campaign. In this case methane was the dominant source of formaldehyde and good agreement (typically within 20\%) was found between measurements and modelled formaldehyde concentrations. However, as shown in Table 3, in other campaigns the models can either under or over predict formaldehyde concentrations.

In this study we have used the Master Chemical Mechanism (MCM) (Saunders et al., 2003) to simulate the 
Table 3. Summary of the results from the measured-modelled comparisons of formaldehyde from the literature. ${ }^{\mathrm{a}}$ Daily mean. ${ }^{\mathrm{b}}$ Value read from a graph (Peak diurnal value). ${ }^{\mathrm{c}}$ Result from summer intensive.

\begin{tabular}{|c|c|c|c|c|}
\hline Authors & Environment & Model constraints & Typical $[\mathrm{HCHO}] / \mathrm{pptv}$ & $\begin{array}{l}\text { Under/Over predic- } \\
\text { tion }\end{array}$ \\
\hline Weller et al. (2000) & $\begin{array}{l}\text { Marine, Atlantic } \\
48^{\circ} \mathrm{N}-35^{\circ} \mathrm{S}\end{array}$ & $\begin{array}{l}\text { Photochemical box model based } \\
\text { on } \mathrm{CH}_{4}+\mathrm{CO} \text { photo oxidation. }\end{array}$ & $580 \pm 160^{\mathrm{a}}$ & $\begin{array}{l}\text { Under predicted by a } \\
\text { factor of } 2\end{array}$ \\
\hline Ayers et al. (1997) & $\begin{array}{l}\text { Coastal, Cape Grim, } \\
\text { Australia }\end{array}$ & $\begin{array}{l}\text { Photochemical box model based } \\
\text { on } \mathrm{CH}_{4}+\mathrm{CO} \text { photo oxidation in- } \\
\text { cludes dimethyl sulphide mecha- } \\
\text { nism }\end{array}$ & $400 \pm 50^{\mathrm{b}}$ & $\begin{array}{l}\text { Under predicted by a } \\
\text { factor of } 2\end{array}$ \\
\hline Wagner et al. (2002) & Marine, Indian Ocean & $\begin{array}{l}\text { MCM 2. Photochemical oxida- } \\
\text { tion of } \mathrm{CH}_{4} \text { and NMVOC }\end{array}$ & $200 \pm 70^{\mathrm{a}}$ & $\begin{array}{l}\text { Over predicted by } \\
12 \%\end{array}$ \\
\hline Zhou et al. (1996) & Free Tropospheric air & $\begin{array}{l}\text { Simple box model based on } \\
\mathrm{CH}_{4} \text { chemistry, constrained to } \\
\mathrm{CH}_{3} \mathrm{COOH}\end{array}$ & $211 \pm 104^{c}$ & Over predict \\
\hline Liu et al. (1992) & Free Tropospheric air & $\begin{array}{l}\text { Photochemical box model based } \\
\text { on } \mathrm{CH}_{4}\end{array}$ & $105 \pm 42$ & Over predict \\
\hline Jacob et al. (1996) & $\begin{array}{l}\text { South Atlantic } \\
\text { (Aircraft) }\end{array}$ & $\begin{array}{l}\text { Photochemical box model } \\
\text { includes } \mathrm{CH}_{4} \text {, inorganic chem- } \\
\text { istry and NMVOCs (exc. } \\
\mathrm{CH}_{3} \mathrm{OH}+\mathrm{CH}_{3} \mathrm{CHO} \text { ) }\end{array}$ & 110 & Over predict \\
\hline Fried et al. (2003) & $\begin{array}{l}\text { Marine, Pacific } \\
\text { (Aircraft) }\end{array}$ & $\begin{array}{l}\text { NASA Langley box model, con- } \\
\text { strained by observations includ- } \\
\text { ing oVOCs }\end{array}$ & $\begin{array}{l}\text { (Average } 2-4 \mathrm{~km}) \\
196 \pm 161\end{array}$ & Equivalent \\
\hline Frost et al. (2002) & $\begin{array}{l}\text { Marine, North At- } \\
\text { lantic, (Aircraft) }\end{array}$ & $\begin{array}{l}\text { Photochemical box model in- } \\
\text { cludes NMHC, and constrained } \\
\text { to measurements. However some } \\
\text { values were taken from other } \\
\text { campaigns. }\end{array}$ & $\begin{array}{l}\text { (Average } 0-2 \mathrm{~km} \text { ) } \\
410 \pm 0.11\end{array}$ & $\begin{array}{l}\text { Under predicted by a } \\
\text { factor of } 2\end{array}$ \\
\hline
\end{tabular}

formaldehyde concentration based on two models. The "clean" model used only a very small subset of the MCM based on methane and CO chemistry whilst the "full-oxy" model was based on a mechanism originating from $\mathrm{CO}$, $\mathrm{CH}_{4}, 23$ hydrocarbons (including isoprene) (Lewis et al., 2005), DMS, chloroform and three oxygenated compounds (methanol, acetaldehyde and acetone) (Hopkins et al., 2003; Lewis et al., 2005). During the simulations the model was constrained to $15 \mathrm{~min}$ averages of the hydrocarbons, $\mathrm{H}_{2}$, $\mathrm{O}_{3}, \mathrm{NO}, \mathrm{NO}_{2}, \mathrm{H}_{2}$ ), temperature and the measured photolysis rates of $\mathrm{O}_{3}, \mathrm{NO}_{2}, \mathrm{HONO}, \mathrm{HCHO}, \mathrm{CH}_{3} \mathrm{COCH}_{3}$ and $\mathrm{CH}_{3} \mathrm{CHO}$. The model included parameters for heterogeneous uptake and dry deposition and was run for several days (typically 2-3) to initialize the values of some species which were not constrained.

Figures $8 \mathrm{a}$ and $\mathrm{b}$ show comparisons of the models with the experimental data for two periods. Figure 8a is for JD221222 during the westerly airflows when both instruments observed a pronounced diurnal variation. For these conditions the full-oxy model is clearly in better agreement with the UEA data, although the shape of the diurnal pattern does not produce the diurnal profiles observed by either technique, particularly the decrease in concentration in the afternoon and evening of JD221.

Figure $8 b$ shows a comparison of the clean and full-oxy models with the experimental data for the period 15-21 August. The predictions from the full-oxy model are in reasonable agreement with the formaldehyde levels observed from UoL apparatus. In general the model does not do a particularly good job in predicting the fine structure of the formaldehyde concentrations (an exception being the sharp increase in concentrations in the early afternoon of 16 August, observed by both experimental techniques), but this is to be expected from a box model.

Figure $8 \mathrm{~b}$ also highlights the significant contribution that the higher hydrocarbons and particularly the oxygenated species make to the predicted formaldehyde concentration. This observation is in good agreement with the analysis by Wagner et al. (2002), where even in the much less complex conditions of the remote Indian Ocean, only $77 \%$ of $\mathrm{HCHO}$ originates from methane, the other $23 \%$ coming from ethane, ethene, propene, isoprene, acetone and DMS, all at concentrations significantly lower than those encountered at Mace Head. Our model highlights the importance of acetaldehyde 
on formaldehyde generation, but unfortunately acetaldehyde was not considered by Wagner.

A rate of production analysis also emphasises the domination $(>70 \%)$ of the $\mathrm{CH}_{3} \mathrm{O}_{2}+\mathrm{NO}$ reaction as the loss mechanism for $\mathrm{CH}_{3} \mathrm{O}_{2}$ for [NO] in the region of $10 \mathrm{pptv}$. Under these conditions formation of the $\mathrm{CH}_{3} \mathrm{OOH}$ reservoir is limited and therefore the potential for carbon removal via $\mathrm{CH}_{3} \mathrm{OOH}$ dry deposition is relatively small.

There have been several recent formaldehyde measurement/model comparisons in the North Atlantic environment (Weller et al., 2000; Frost et al., 2002; Fried et al., 2003) in which all under predict measured formaldehyde concentrations to some degree. Weller et al. compared measured average formaldehyde concentrations of $580 \pm 160 \mathrm{pptv}$ from a North Atlantic cruise with calculated values based on a box model. On the basis of measured alkane concentrations, they argued that methane should be the major source, but noted that alkenes (not measured) could be a significant source. The standard methane model under predicted the measurements by 250 pptv. Better agreement was found by introducing a formaldehyde production channel from Reaction (R2);

$$
\mathrm{CH}_{3} \mathrm{O}_{2}+\mathrm{HO}_{2} \rightarrow \mathrm{HCHO}+\mathrm{H}_{2} \mathrm{O}+\mathrm{O}_{2}
$$

based on arguments by Ayers et al. (1997). Making channel (Reaction R17) $40 \%$ of the total reaction increased average formaldehyde concentrations by $80 \mathrm{pptv}$. Increasing the rate coefficient for $\mathrm{OH}$ abstraction and changing the branching ratios for the $\mathrm{OH}+$ methylhydrogenperoxide reaction within values suggested in the literature increased formaldehyde by 50 pptv over the base model. Frost et al. generally underestimated airborne formaldehyde measurements from the NARE 97 campaign by between 130 and 180 pptv ( factor two) using a methane/hydrocarbon model. They carried out a sensitivity analysis and concluded that it was not possible to bridge the gap between measurement and model within the currently understood uncertainties in the model parameters but noted that VOCs not measured or considered in the model could represent the missing source. Finally, Fried et al. report generally good agreement between measurement and model for the TOPSE 2000 experiment, although again there is significant under prediction at high latitudes over North Atlantic regions (Fried et al., 2003).

Our modelling work emphasises the importance of oxygenated species and particularly acetaldehyde and methanol in generating significant concentrations of formaldehyde. We would therefore suggest that these species, measured values of which were not considered in the above modelling studies, as a potential source of missing formaldehyde and recommend that concurrent measurements of all oxygenated species are considered for future campaigns.

During the night (from 20:00-04:00 GMT) deposition and entrainment are the only removal processes for formaldehyde. From the averaged diurnal formaldehyde profiles for westerly air masses (Figs. 5a, b) both experimental techniques show a decrease of approximately $150 \mathrm{pptv}$ formaldehyde during this period. Assuming that physical processes can be represented by a first order loss, this allows a prediction of the initial concentration at the start of the deposition only period.

$$
[\mathrm{HCHO}]_{0}-150=[\mathrm{HCHO}]_{0} e^{-k t}
$$

For a sum of deposition and entrainment equal to $1 \times 10^{-5} \mathrm{~s}^{-1}$, based on the reported deposition and entrainment velocities of $0.4 \mathrm{~cm} \mathrm{~s}^{-1}$ (Wagner et al., 2002) and a boundary layer height of $800 \mathrm{~m}$ (Norton et al., 2006), Eq. (1) predicts $[\mathrm{HCHO}]_{0}$ of $600 \mathrm{pptv}$, in between the two observations. Currently, uncertainties in boundary layer height $( \pm 200 \mathrm{~m})$ and deposition velocities (up to $100 \%$ ) are such that the calculation range can encompass both observations. However, reductions in such uncertainties could help differentiate between the two observations.

\subsection{Implications for $\mathrm{HO}_{\mathrm{x}}$ production}

Formaldehyde is an important photolytic source of radicals in the troposphere (Reaction R13). The MCM has been used to quantify the influence of the measured formaldehyde levels on $\left[\mathrm{HO}_{\mathrm{x}}\right]$. Variations in formaldehyde levels have relatively little influence on $\mathrm{OH}$ radical concentrations as while increased formaldehyde generates more $\mathrm{HO}_{\mathrm{x}}$ radicals, formaldehyde is also a significant HO sink via Reaction (R10). Using either set of formaldehyde measurements changed the predicted $\mathrm{OH}$ concentration by $<2 \%$ under typical westerly conditions. Increased formaldehyde concentrations have a more pronounced positive effect on $\mathrm{HO}_{2}$ chemistry, although the relationship is not $1: 1$, being buffered by relatively complex radical interconversion. Increasing formaldehyde concentrations by $50 \%$ produces between a 15-25\% increase in $\mathrm{HO}_{2}$ concentrations. It should be noted that currently (Sommariva, 2004) the MCM tends to overpredict $\mathrm{HO}_{2}$ concentrations by up to a factor of two. As noted earlier, formaldehyde may have a more pronounced influence on $\mathrm{HO}_{\mathrm{x}}$ production in other environments e.g. where a lack of ozone or water prevents $\mathrm{OH}$ generation via $\mathrm{O}\left({ }^{1} \mathrm{D}\right)$ production.

\section{Conclusions}

Formaldehyde concentrations, measured by two different techniques during the NAMBLEX campaign appear to be correlated, but exhibit a significant offset. Joint calibrations and subsequent intercomparison experiments have failed to identify the cause of the systematic errors present in one, or both sets of apparatus. The laboratory intercomparisons at NPL in the presence of water vapour were inconclusive and further work in planned in this area in a new atmospheric chamber in Leeds. 
Formaldehyde continues to be a difficult molecule to measure with intercomparisons reporting varying levels of agreement. A recent comparison from the BERLIOZ campaign (Grossmann et al., 2003) reported formaldehyde measurements from a DOAS system to be $30 \%$ higher than those from a commercial Hantzsch system. Still more recently, an intercomparison in Milan (Hak et al., 2005) gave good agreement between FTIR, DOAS, Hantzsch and DNPH techniques with the slopes of the Hantzsch and DOAS regression line not significantly differing from one. However, it should be noted that formaldehyde concentrations during this intercomparison (2-13 ppbv) were significantly higher than those encountered at Mace Head. More work is required to identify systematic errors in formaldehyde detection, especially at low concentration levels.

Comparison with previous formaldehyde measurements in the North Atlantic suggests typical concentrations between 300-800 pptv under clean background conditions. The UEA data lie at the low end of this range, the UoL data just above the upper limit.

Previous campaigns have shown a strong positive correlation between formaldehyde and acetaldehyde and with a $\mathrm{HCHO}$ to $\mathrm{CH}_{3} \mathrm{HCO}$ ratio of approximately 2:1. A good correlation has been observed between the UoL formaldehyde data and acetaldehyde measurements from the University of York. The ratio of concentrations is in agreement with previous work.

Both instruments show a distinct diurnal profile during periods of consistent westerly airflow with an amplitude of 150-250 pptv. This is the expected behaviour of a photochemical intermediate, but such behaviour has not always been observed in previous campaigns, either due to sampling frequency or because of fluctuations in the concentrations of the various air masses arriving at the receptor. This latter factor is especially important in shipborne cruises.

Modelling studies from the latter part of the campaign predict concentrations between the two experimental measurements, but more importantly, highlight the importance of oxygenates in formaldehyde production. The involvement of oxygenated species in formaldehyde production may explain some of the under predictions of simple methane only models. The concentrations of formaldehyde predicted by the MCM for an earlier part of the campaign are in better agreement with UEA data.

Acknowledgements. The authors would like to acknowledge the help of P. G. Quincey, N. Martin at NPL and NERC for funding the NAMBLEX project. T. J. Still and S. Al-Haider thank NERC and the Kuwaiti Government respectively for the funding of $\mathrm{PhD}$ studentships.

Edited by: P. Monks

\section{References}

Ayers, G. P., Gillett, R. W., DeServes, C., and Cox, R. A.: Formaldehyde production in clean marine air, Geophys. Res. Lett., 24, 401-404, 1997.

Cardenas, L. M., Brassington, D. J., Allan, B. J., Coe, H., Alicke, B., Platt, U., Wilson, K. M., Plane, J. M. C., and Penkett, S. A.: Intercomparison of formaldehyde measurements in clean and polluted atmospheres., J. Atmos. Chem., 37, 53-80, 2000.

Carslaw, N., Creasey, D. J., Heard, D. E., Jacobs, P. J., Lee, J. D., Lewis, A. C., McQuaid, J. B., Bauguitte, S., Pilling, M. J., Penkett, S. A., Monks, P. S., and Salisbury, G.: Comparisons of model concentrations of $\mathrm{OH}, \mathrm{HO}_{2}$ and $\mathrm{RO}_{2}$ with measurements during EASE 97, J. Geophys. Res., 107(D14), 4190, doi:10.1029/2001JD001568, 2002.

Fried, A., Crawford, J., Olsen, J., Walega, J., Potter, W., Wert, B., Jordan, C., Anderson, B., Shetter, R., Lefer, B., Blake, D. R., Blake, N. J., Meinardi, S., Heikes, B., O'Sullivan, D., Snow, J., Fuelberg, H., Kiley, C. M., Sandholm, S., Tan, D., Sachse, G. W., Singh, H. B., Faloona, I., Harward, C. N., and Carmichael, G. R.: Airbourne tuneable diode laser measurements of formaldehyde during TRACE-P. Distributions and model comparisons., J. Geophys. Res., 108(D20), 8798, doi:10.1029/2003JD003451, 2003.

Fried, A., Lee, Y.-N., Frost, G., Wert, B., Henry, B., Drummond, J. R., Hubler, G., and Jobson, T.: Airborne formaldehyde measurements over the North Atlantic during the 1997 NARE campaign: Instrument comparisons and distributions., J. Geophys. Res., 107, 4039, doi:10.1029/2000JD260, 2002.

Fried, A., Wang, Y., Cantrell, C., Wert, B., Walega, J., Ridley, B., Atlas, E., Shetter, R., Lefer, B., Coffey, M. T., Hannigan, J., Blake, D. R., Blake, N. J., Meinardi, S., Talbot, R., Dibb, J., Scheuer, E., Wingenter, O., Snow, J., Heikes, B., and Ehhalt, D.: Tunable diode laser measurements of formaldehyde during the TOPSE 2000 study: Distribution, trends and model comparisons, J. Geophys. Res., 108(D4), 8365, doi:10.1029/2002JD002208, 2003.

Frost, G. J., Fried, A., Lee, Y.-N., Wert, B., Henry, B., Drummond, J. R., Evans, M. J., Fehsenfeld, F. C., Goldan, P. D., Holloway, J. S., Hubler, G., Jakoubek, R., Jobson, B. T., Knapp, K., Kuster, W. C., Roberts, J., Rudolph, J., Ryerson, T. B., Stohl, A., Stroud, C., Sueper, D. T., Trainer, M., and Williams, J.: Comparisons of box model calculations and measurements of formaldehyde from the 1997 North Atlantic Regional Experiment, J. Geophys. Res., 107(D8), 4060, doi:10.1029/2001JD000896, 2002.

Gilpin, T., Apel, E., Fried, A., Wert, B., Calvert, J. G., Zhang, G. F., Dasgupta, P., Harder, J. W., Heikes, B., Hopkins, B., Westberg, H., Kleindienst, T., Lee, Y. N., Zhou, X. L., Lonneman, W., and Sewell, S.: Intercomparison of six ambient formaldehyde measurement techniques, J. Geophys. Res., 102(D17), 21 161$21188,1997$.

Grossmann, D., Moortgat, G. K., Kibler, M., Schlomski, S., Bachmann, K., Alicke, B., Geyer, A., Platt, U., Hammer, M.-U., Vogel, B., Mihelcic, D., Hofzumahaus, A., Holland, F., and Volz-Thomas, A.: Hydrogen peroxide, organic peroxides, carbonyl compounds and organic acids measured at Pabstthum during BERLIOZ, J. Geophys. Res., 108(D4), 8250, doi:10.1029/2001JD001096, 2003.

Hak, C., Pundt, I., Trick, S., Kern, C., Platt, U., Dommen, J., Ordonez, C., Prevot, A. S. H., Junkermann, W., Astorga-Llorens, 
C., Larson, B. R., Mellqvist, J., Strandberg, A., Yu, Y., Galle, B., Kleffman, J., Lorzer, J. C., Braathen, G. O., and Volkamer, R.: Intercomparison of four different in-situ techniques for ambient formaldehyde measurements in urban air, Atmos. Chem. Phys., 5, 2897-2945, 2005,

http://www.atmos-chem-phys.net/5/2897/2005/.

Harris, G. W., Klemp, D., Zenker, T., and Burrows, J. P.: Tuneable diode laser measurements of trace gases during the 1988 Polarstern cruise., J. Atmos. Chem., 15, 315-326, 1992.

Heard, D. E., Carpenter, L. J., Creasey, D. J., Hopkins, J. R., Lee, J. D., Lewis, A. C., Pilling, M. J., Seakins, P. W., Carslaw, N., and Emmerson, K. M.: High levels of the hydroxyl radical in the winter urban troposphere, Geophys. Res. Lett., 31(18), L18112, doi:10.1029/2004GL020544, 2004.

Heard, D. E., Read, K. A., Methven, J., et al.: The North Atlantic Marine Boundary Layer Experiment (NAMBLEX), Mace Head, summer 2002, campaign overview, Atmos. Chem. Phys., 6 2241-2272, 2006.

Hopkins, J. R., Lewis, A. C., and Read, K. A.: A two-column method for long-term monitoring of non-methane hydrocarbons and oxygenated volatile organic compounds, J. Environ. Monit., 5, 8-13, 2003.

Hopkins, J. R., Still, T., Al-Haider, S., Fisher, I. R., Lewis, A. C., and Seakins, P. W.: A Simplified Apparatus for Ambient Formaldehyde Detection via GC-pHID, Atmos. Environ., 37, 2557-2563, 2003.

Hunter, M. C., Bartle, K. D., Lewis, A. C., McQuaid, J. B., Myers, P., Seakins, P. W., and Van Tilburg, C.: The use of the Helium Ionization Detector for Gas Chromatographic Monitoring of Trace Atmospheric Components, J. High Res. Chrom., 21, 75-78, 1998.

Hunter, M. C., Bartle, K. D., Seakins, P. W., and Lewis, A. C.: Direct measurement of atmospheric formaldehyde using gas chromatography-pulsed discharge ionisation detection, Analytical Communications, 36, 101-104, 1999.

Jacob, D. J., Heikes, B., Fan, S. M., Logan, J. A., Mauzerall, D. L., Bradshaw, J. D., Singh, H. B., Gregory, G. L., Talbot, R., Blake, D. R., and Sachse, G. W.: Origin of ozone and $\mathrm{NO}_{\mathrm{x}}$ in the tropical troposphere: A photochemical analysis of aircraft observations over the South Atlantic basin, J. Geophys. Res., 101(D19), 24 235-24 250, 1996.

Lewis, A. C., Hopkins, J. R., Carpenter, L. J., Stanton, J. C., Read, K. A., and Pilling, M. J.: Sources and sinks of acetone, methanol, and acetaldehyde in North Atlantic air, Atmos. Chem. Phys., 5, 1963-1974, 2005, http://www.atmos-chem-phys.net/5/1963/2005/.

Liu, S. C., Trainer, M., Carrol, M. A., Hubler, G., Montzka, S. A., Norton, R. B., Ridley, B., Walega, J., Atlas, E., Heikes, B., Huebert, B. J., and Warren, W.: A study of the photochemistry and ozone budget during the Mauna Loa Observatory Photochemistry Experiment, J. Geophys. Res., 97(D10), 10463-10471, 1992.

Norton, E. G., Vaughan, G., Methven, J., Coe, H., Brooks, D., Gallagher, M., and Longley, I.: Boundary layer structure and decoupling from synoptic scale flow during NAMBLEX, Atmos. Chem. Phys., 6, 433-445, 2006,

http://www.atmos-chem-phys.net/6/433/2006/.
Pope, F. D., Smith, C. A., Davis, P. R., Shallcross, D. E., Ashfold, M. N. R., and Orr-Ewing, A. J.: Photochemistry of formaldehyde under tropospheric conditions, Faraday Discuss., 130, 59 73, doi:10.1039/b419227c, 2005.

Qian, H. B., Turton, D., Seakins, P. W., and Pilling, M. J.: A Laser Flash Photolysis/IR Diode Laser Absorption Study of the Reaction of Chlorine Atoms with Selected Alkanes, Int. J. Chemical Kinetics, 34, 86-94, 2002.

Ramacher, B., Rudolph, J., and Koppmann, R.: Hydrocarbon measurements during tropsopheric ozone depletion events: Evidence for halogen chemistry., J. Geophys. Res., 104, 3633-3653, 1999.

Saunders, S. M., Jenkin, M. E., Derwent, R. G., and Pilling, M. J.: Protocol for the development of the Master Chemical Mechanism, MCM v3: Tropospheric degradation of non-aromatic VOC., Atmos. Chem. Phys., 3, 161-180, 2003, http://www.atmos-chem-phys.net/3/161/2003/.

Seakins, P. W., Orlando, J. J., and Tyndall, G. S.: The Rate Coefficients and Fraction of Vibrationally Excited $\mathrm{HCl}$ from the Reactions of Chlorine Atoms with Methanol, Ethanol, Acetaldehyde and Formaldehyde., Phys. Chem. Chem. Phys., 6, 2224-2229, 2004.

Solberg, S., Dye, C., Schmidbauer, N., Herzog, A., and Gehrig, R.: Carbonyls and nonmethane hydrocarbons at rural European sites from the Mediterranean to the Arctic, J. Atmos. Chem., 25, 3366, 1996.

Sommariva, R.: Understanding Field Measurements through a Master Chemical Mechanism, School of Chemistry, Leeds, University of Leeds, 2004.

Sommariva, R., Haggerstone, A. L., Carpenter, L. J., Carslaw, N., Creasey, D. J., Heard, D. E., Lee, J. D., Lewis, A. C., Pilling, M. J., and Zador, J.: $\mathrm{OH}$ and $\mathrm{HO}_{2}$ chemistry in clean marine air during SOAPEX-2, Atmos. Chem. Phys., 4, 839-856, 2004, http://www.atmos-chem-phys.net/4/839/2004/.

Tanner, R. L., Zielinska, B., Uberna, E., Harsfield, G., and McNichol, A. P.: Concentrations of carbonyl compounds and the carbon isotopy of formaldehyde at a coastal site in Nova Scotia during the NARE summer intensive, J. Geophys. Res., 101(D22), 28 961-28 970, 1996.

Wagner, V., Schiller, C., and Fischer, H.: Formaldehyde measurements in the marine boundary layer of the Indian Ocean during the 1999 INDOEX cruise, J. Geophys. Res., 106(D22), 28 529$28538,2001$.

Wagner, V., von Glasow, R., Fischer, H., and Crutzen, P. J.: Are formaldehyde measurements in the marine boundary layer suitable for testing the current understanding of $\mathrm{CH}_{4}$ photooxidation?, J. Geophys. Res., 107(D3), 4029, doi:10.1029/2001JD000722, 2002.

Weller, R., Schrems, O., Boddenberg, A., Gab, S., and Gautrois, M.: Meridional distribution of hydroperoxides and formaldehyde in the marine boundary layer of the Atlantic $\left(48^{\circ} \mathrm{N}-35^{\circ} \mathrm{S}\right)$ measured during the Albatross campaign, J. Geophys. Res., 105, 14 401-14 412, 2000.

Zhou, X. L., Lee, Y.-N., Newman, L., Chen, X. H., and Mopper, K.: Tropospheric formaldehyde concentration at the Mauna Loa observatory during MLOPEX 2, J. Geophys. Res., 101(D9), 14711-14 719, 1996. 